АПОЛОГИЯ СУМАСШЕДШЕГО, ИЛИ РАЗУМ ПРОТИВ БЕЗУМИЯ ТОЛПЫ Заметки главного редактора

\author{
Владимир Кантор \\ Доктор философских наук, \\ ординарный профессор Национального \\ исследовательского университета
} «Высшая школа экономики» (НИУ ВШЭ), заведующий Международной лабораторией

исследований русско-европейского интеллектуального диалога (НИУ ВШЭ),

главный редактор журнала

«Философические письма.

Русско-европейский диалог», член Союза

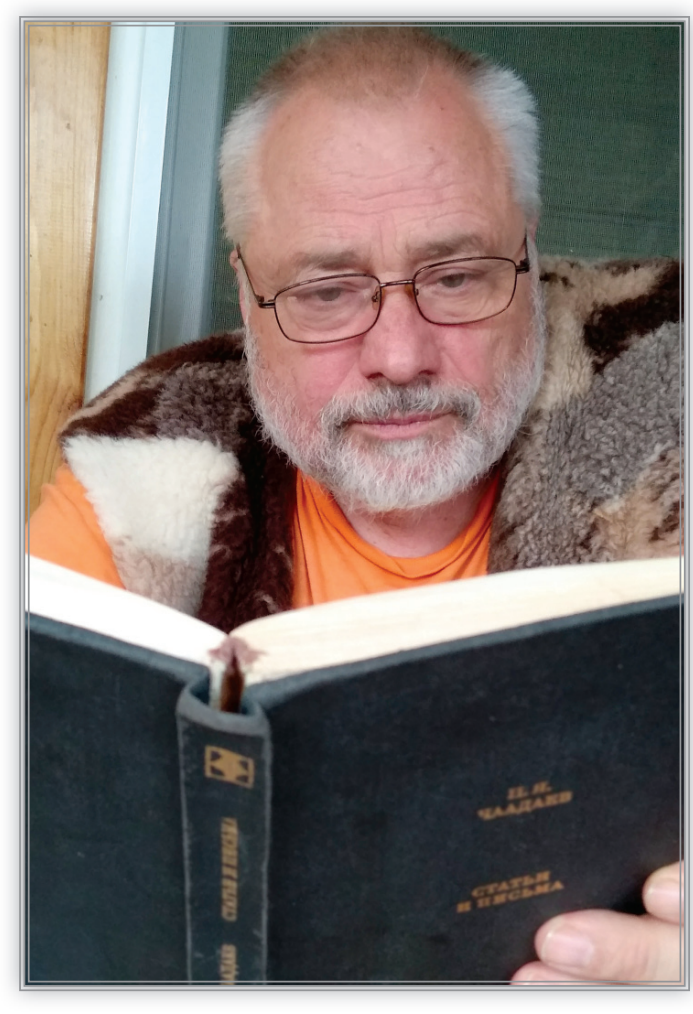

российских писателей, член Общественного совета Фонда Достоевского

Адрес: ул. Старая Басманная, 21/4, Москва, Российская Федерация 105066, каб. 215. E-mail: vlkantor@mail.ru

\title{
DOI 10.17323/2658-5413-2019-2-4-12-34
}

Искусный врач, сняв катаракту, надевает повязку на глаза больного; если же он не сделает этого, больной ослепнет навеки. В нравственном мире - то же, что в физическом; человеческое сознание также требует постепенности. Если Провидение вручило вам свет слишком яркий, слииком ослепительный для наших потемок, не лучше ли вводить его понемногу, нежели ослеплять людей как бы Фаворским сиянием и заставлять их падать лицом на землю? Я вижу ваше назначение в ином; мне кажется, что вы призваны протягивать руку тем, кто жаждет подняться, и приучать их к истине, не вызыьвая в них того бурного потрясения, которое не всякий может вынести. Я твердо убеждена, ито именно таково ваше призвание на земле; иначе зачем ваша наружность производила бы такое необыкновенное впечатление даже на детей? Зачем были бы даны вам такая сила внушения, такое красноречие, такая страстная убежденность, такой возвышенный и глубокий ум? Зачем так пылала бы в нас любовь $\kappa$ человечеству?

Зачем вама жизнь была бы полна стольких треволнений?

Зачем столько тайных страданий, столько разочарований?..

И можно ти думать, что все это случилось без предустановленной цели, которой вам суждено достигнуть, никогда не падая духом и не теряя терпения, ибо с вашей стороны это значило бы усомниться в Провидении?

Е.Г. Левачева П.Я. Чаадаеву (1834-1835)

Научный электронный журнал. Философические письма. Русско-европейский диалог. Том (2) №4-2019 
$\mathrm{K}^{\mathrm{o}}$ оллективное бессознательное существует. Коллективный разум есть порождение тоталитарной идеологии, выросшей из первобытно-племенной психологии. Разум - достояние индивида. Это очень хорошо понимал Чаадаев. «Массы, - писал он в первом Философическом письме, подчиняются известным силам, стоящим у вершин общества. Непосредственно они не размышляют. <..> Незначительное меньшинство мыслит, остальная часть чувствует, в итоге же получается общее движение. $<\ldots>$ А теперь я вас спрошу, где наши мудрецы, где наши мыслители? Кто из нас когда-либо думал, кто за нас думает теперь?» (Чаадаев, 1991а: 329).

Итак, мыслитель, мудрец, стоящий вне толпы, дружил с такими же (Пушкин, А. Тургенев, Тютчев, Хомяков). Нельзя также забывать о генетике: отец умер рано, следом умерла мать,

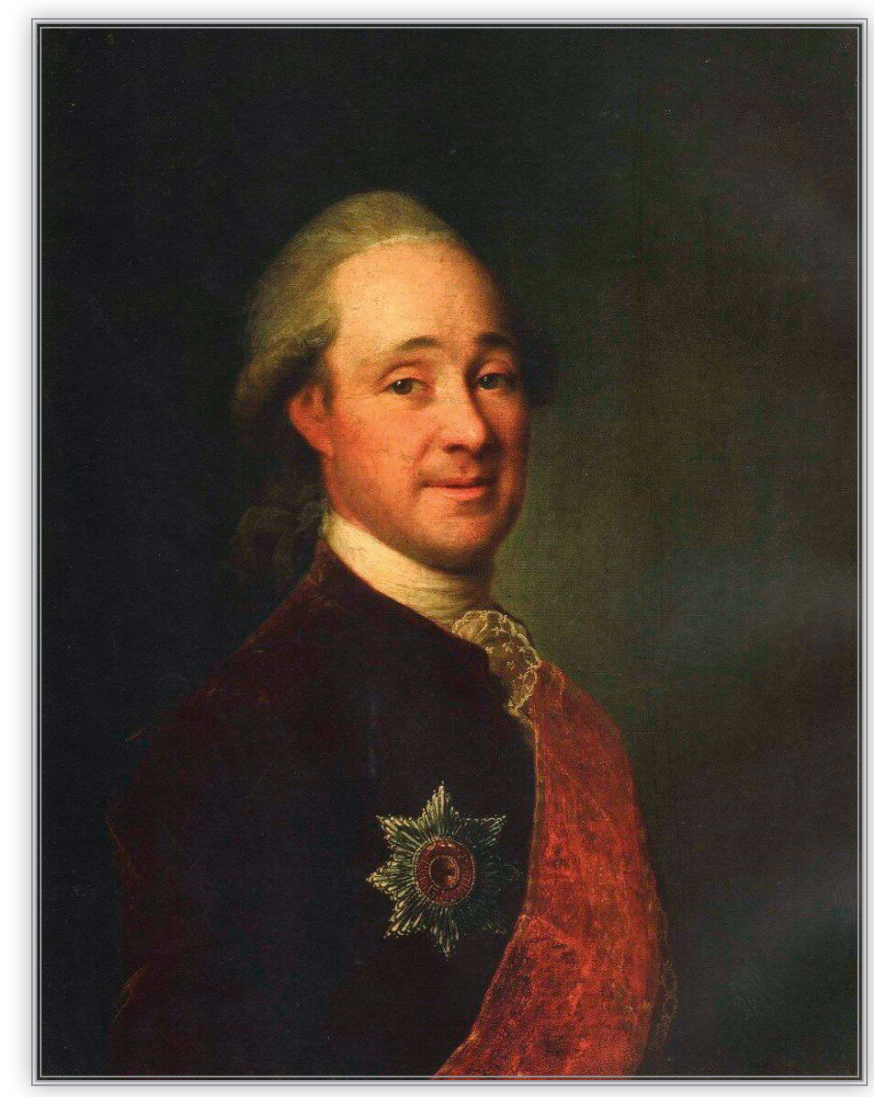

Д. Г. Левицкий. Портрет князя Михаила Михайловича Щербатова. Холст, масло. 1781. Музей В.А. Тропинина и московских художников его времени и он воспитывался в доме родной тетки, княжны Анны Михайловны Щербатовой, то есть был родным внуком князя Михаила Щербатова, историка и автора самого резкого дочаадаевского сочинения «О повреждении нравов в России». Правда, это сочинение стало известно много позже, но исторические исследования князя читались образованными русскими. Карамзин, кумир интеллектуальной элиты тех лет, высоко ценил Щербатова.

И это добавляло шарма гусару, с которым задружился юный Пушкин. Дружбу пронес через всю жизнь.

Когда соединим слова любви и руки?

Когда услышу я сердечный твой привет?..

Как обниму тебя! Увижу кабинет,

Где ты всегда мудрец, а иногда мечтатель

И ветреной толпы бесстрастный наблюдатель.

Приду, приду я вновь, мой милый домосед,

С тобою вспоминать беседы прежних лет...

(«Чаадаеву», 1821) 


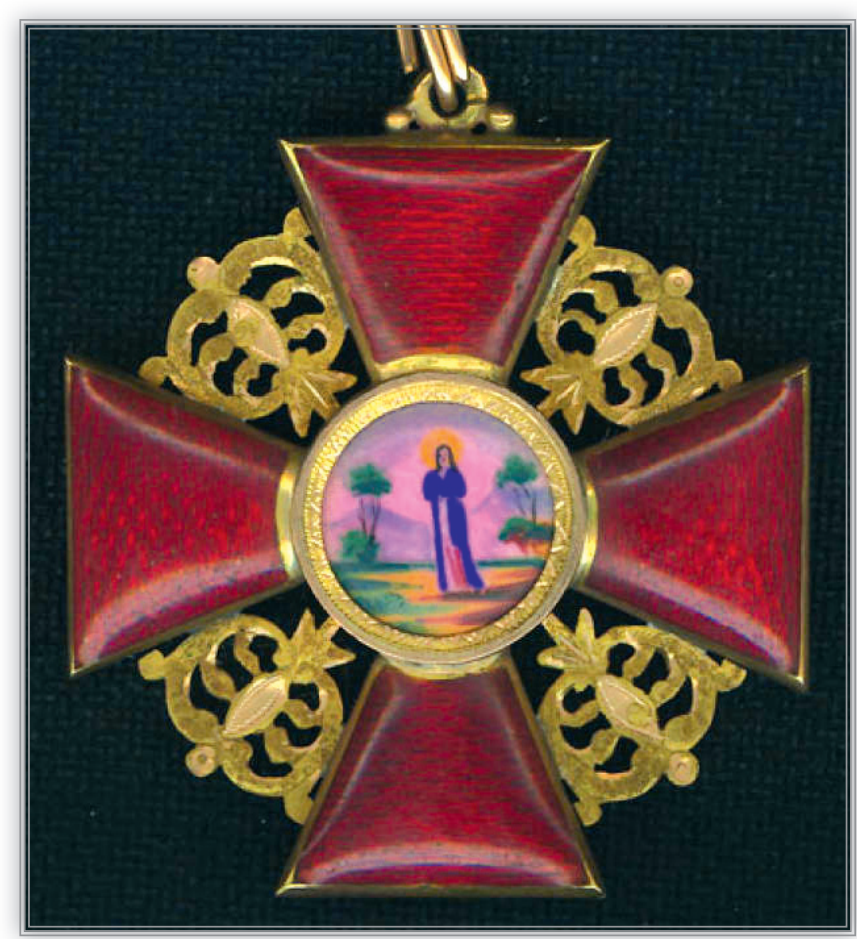

Орден св. Анны

Как известно, Пушкин познакомился с Чаадаевым у Карамзина. С того момента гусарский офицер, несостоявшийся Перикл, увы, не давший устроения русскому обществу - как создатель римской республики Луций Юний Брут, выступивший против последнего царя, - стал фактически постоянным духовным собеседником поэта. «Мой милый домосед» - так называл Пушкин Чаадаева, а тот, между прочим, был воин, что порой забывается. И военному героизму мыслителя есть свидетельство: «В знаменитом сражении при Кульме (август 1813 г.) 1-я гвардейская дивизия, в которую входил Семеновский полк, прикрывала отход союзной армии после неудачи под Дрезденом. Русская гвардия проявила исключительную отвагу. Семеновский полк сражался несколько дней подряд; во 2-м батальоне семеновцев, например, вышли из строя все офицеры, кроме прапорщика И. Д. Якушкина, который принял командование. Прапорщик П. Я. Чаадаев со стрелками 3-го батальона отличился при атаке горы Кольберг. За особую храбрость награжден орденом Анны 3-й степени» (Жихарев, 1989: 364).

Надо полагать, что героическое прошлое старшего друга придавало ему дополнительное очарование в глазах лицеиста, впоследствии не раз обращавшегося в своих текстах к сюжетам войны с Наполеоном. Как известно, одним из прямых следствий победы над французами и пребывания дворян в Европе стало движение декабристов. Казалось бы, свободолюбивый гусар и мыслитель должен был оказаться в центре этого движения. Импульсивный юный Пушкин торопил Чаадаева:

Пока свободою горим,

Пока сердца для чести живы,

Мой друг, отчизне посвятим

Души прекрасные порывы!

Товарищ, верь: взойдет она,

Звезда пленительного счастья,

Россия вспрянет ото сна,

И на обломках самовластья

Напишут наши имена!

(«К Чаадаеву», 1818) 
Чаадаев же в 1823 г. вышел в отставку, оставив военную службу. Как известно, он был послан в Троппау к императору своим военным командиром, князем И. В. Васильчиковым, с докладом об «истории» в Семеновском полку. Чаадаев, сам служивший в свое время в Семеновском полку, переживал за бывших однополчан, воспротивившихся самодурству нового командира, полковника Ф. Е. Шварца. Существует немало версий его отставки, как правило, пытающихся унизить героя, но я присоединяюсь к трактовке А. А. Кара-Мурзы: «Судя по всему, вызвавшись доложить Александру I о “семеновской истории”, Чаадаев рассчитывал смягчить недовольство царя, представив дело в нужном свете. Однако австрийский канцлер Клеменс Меттерних, исподволь укрепляя свои позиции в Троппау, был, напротив, заинтересован представить безобидную в сущности историю как “военный заговор”. Царь был вынуж-

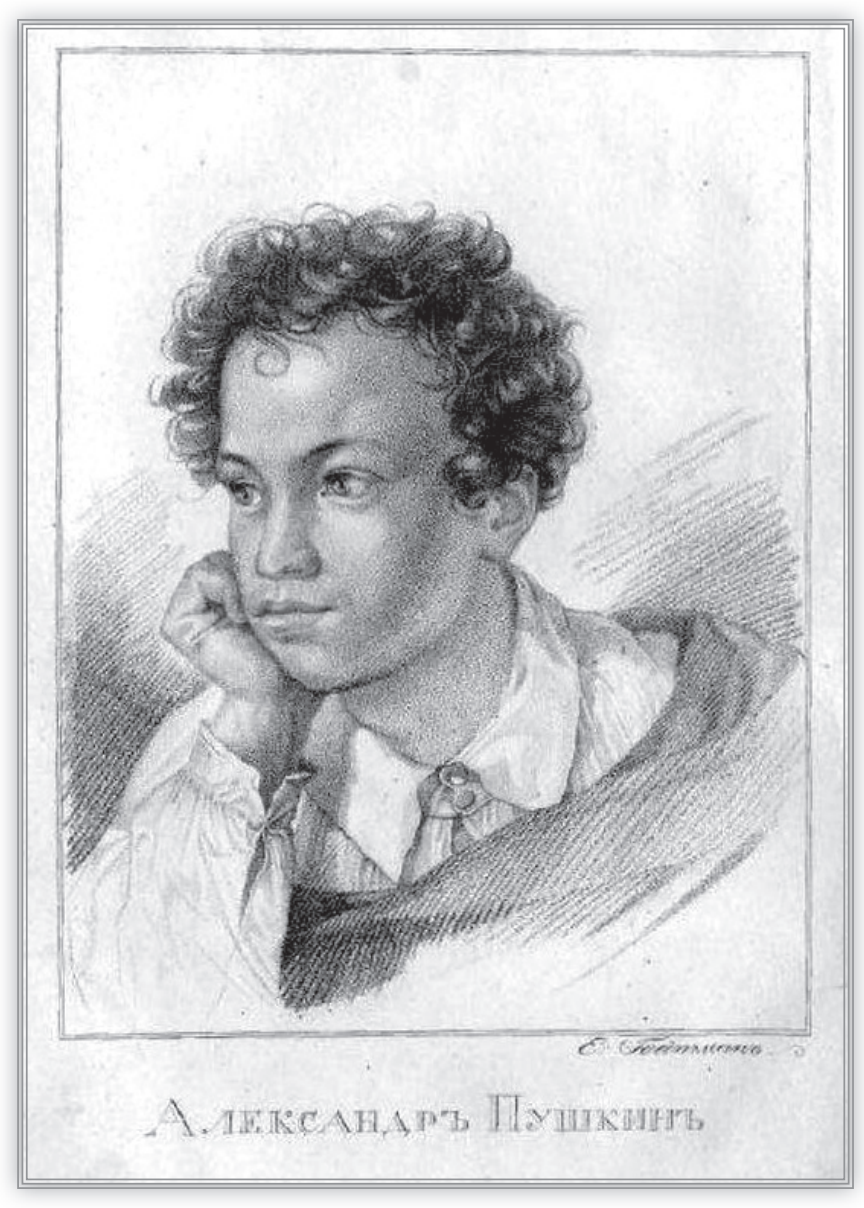

Е. И. Гейтман. А. С. Пушкин. Гравюра на меди. 1822. Этот портрет в издании «Кавказского пленника»

(1822, Типография Н. Греча) стал первым опубликованным изображением поэта ден оправдываться, уверяя союзников, что “ручается головою, что у него в России никаких не будет восстаний”. На что Меттерних с сарказмом отреагировал: “Государь, не теряйте голову; она слишком драгоценна для России и для Европы”. Как бы там ни было, император Александр склонился в итоге к варианту жестких репрессий по отношению к “семеновцам”. Миссия Чаадаева потерпела неудачу, и, чтобы спасти репутацию, он вынужден был подать в отставку. Некоторое время он еще оставался в России, с горечью наблюдая за деградацией так много обещавшего когда-то царствования» (Кара-Мурза, 2019: 8-9). Он уехал на три года в Европу.

Декабрьское восстание произошло без него. Его часто именуют «декабрист без декабря». Вряд ли с этим можно согласиться. Он никогда не пошел бы с толпой, даже «толпой дворян» (как назвал зрелый Пушкин декабристов в «Онегине»). Его возмущало, что будущность страны «разыграна в кости несколькими молодыми людьми между трубкой и стаканом вина» (Чаадаев, 1991б: 106). Восстание 
декабристов он определял в своем знаменитом первом письме как «неизмеримое бедствие, отбросившее нас назад на полвека» (Чаадаев, 1991а: 330). Надо напомнить, что еще два гениальных человека - Грибоедов и Тютчев - не приняли декабристов. Грибоедов говорил о пятидесяти прапорщиках, решивших перевернуть недвижную махину. Тютчев сформулировал свое отношение в очень ясных и грустных стихах:

О жертвы мысли безрассудной,

Вы уповали, может быть,

Что станет вашей крови скудной,

Чтоб вечный полюс растопить!

Едва, дымясь, она сверкнула

На вековой громаде льдов,

Зима железная дохнула -

И не осталось и следов.

(«14-е декабря 1825», 1826)

Грибоедов произнес приговор Чаадаеву, назвав свою трагическую комедию «Горе от ума», где главный герой Чацкий (по мысли Ю. Тынянова, списанный с Чаадаева) объявлен безумным, и не властью, а обществом, «ветреной толпой», ибо слишком много ума бесит толпу, и она расправляется с мыслителем тем или иным способом. Лучше всего объявить его потерявшим ум, выжившим из ума, безумным. Это было написано задолго до катастрофы с Философическим письмом в «Телескопе». И скорее всего связано с неожиданной отставкой Чаадаева поступком безумным, на взгляд обывателя, пусть даже аристократа.

Странное предвидение. Причем образ Чаадаева разбит на несколько персонажей - Чацкого, Ипполита Маркелыча Удушьева и князя Федора, который, по словам старой княгини, тетушки князя, «от женщин бегает, и даже от меня». Это и к Чаадаеву относилось.

Разумеется, странности гениального друга не смущали Пушкина. Любвеобильный поэт не обращал внимания на подчеркнутую строгость по отношению рожденного «в оковах службы царской» гусара к женщинам. Женщины его любили, он их пленял умом, идейной страстью, обликом денди, проводившего часы в своем кабинете, чтобы выглядеть по моде, создавший из флигеля на Басманной (в доме Е. К. Левашовой) своего рода «басманный Ватикан», как иронизировали современники. Поэт Языков определил его как «красивый идол // Строптивых душ и слабых жен!» («К Чаадаеву»). Но, по словам биографа Чаадаева М. И. Жихарева, женщин он не знал и уклонялся от всяких сексуальных контактов, своего рода «монах в миру» или князь Мышкин, которого женщины тоже любили, 


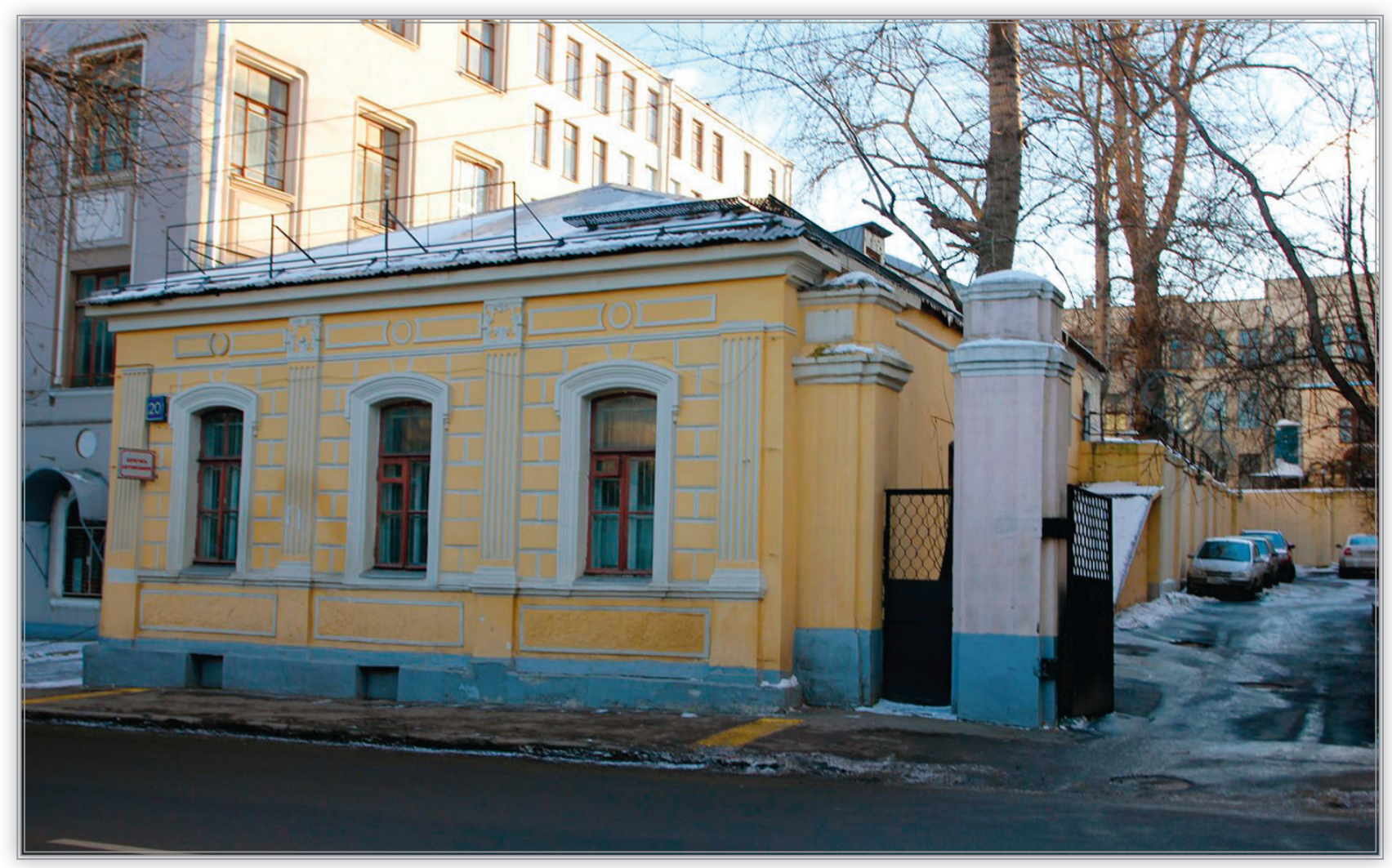

Усадьба Левашевых в Москве, ул. Новая Басманная 20

получая от него только духовную близость. Вот слова Жихарева: «Чаадаев имел огромные связи и бесчисленные дружеские знакомства с женщинами. Тем не менее никто никогда не слыхал, чтобы которой-нибудь из них он был любовником. Вследствие этого обстоятельства он очень рано - лет тридцати пяти - стяжал репутацию бессилия, будто бы происшедшего от злоупотребления удовольствиями. Потом стали говорить, что он во всю свою жизнь не знал женщин. Сам он об этом предмете говорил уклончиво, никогда ничего не определял, никогда ни от чего не отказывался, никогда ни в чем не признавался, многое давал подразумевать и оставлял свободу всем возможным догадкам. Тогда я решился напрямки и очень серьезно сделать ему лично вопрос, на который потребовал категорического ответа: “Правда или нет, что он во всю свою жизнь не знал женщины, если правда, то почему: от чистоты ли нравов, или по другой какой причине?” Ответ я получил немедленный, ясный и определенный: “Ты это все очень хорошо узнаешь, когда я умру". Прошло восемь лет после его смерти, и я не узнал ничего. В прошлом годе, наконец, достоверный свидетель и, без всякого сомнения, из ныне живущих на то единственный, которого я не имею права назвать, сказывал мне, что никогда, ни в первой молодости, ни в более возмужалом возрасте, Чаадаев не чувствовал никакой подобной потребности и никакого влечения к совокуплению, что таковым он был создан. Должно согласиться, что организация такого свойства в высшей степени феноменальна» (Жихарев, 1989: 57-58). И тем не менее его знаменитые письма обращены к даме - Екатерине Пановой. Твор- 


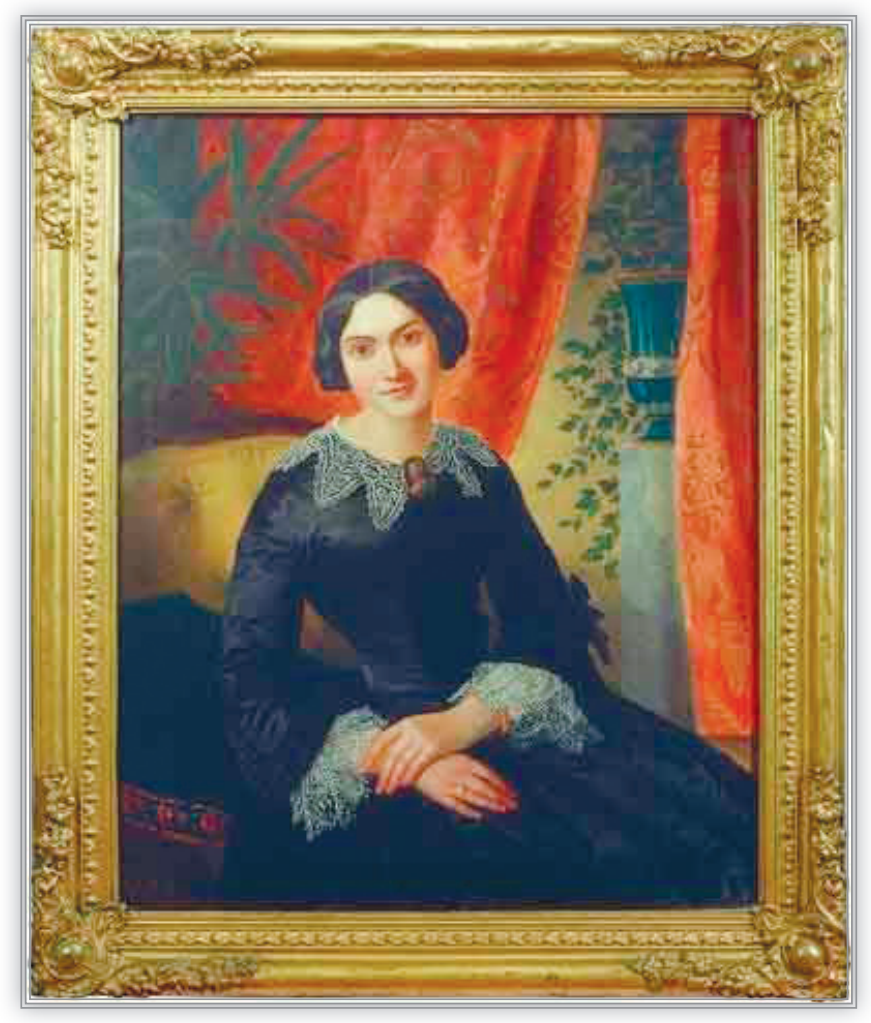

Неизвестный художник.

Портрет Е. Г. Левашовой. 1840-е гг. Холст, масло. Частное собрание. Портрет посмертный, исполнен по неизвестному прижизненному изображению ческому мужчине нужна женщина, способная понимать, ибо понимание Другого - женский дар. Еще Пушкин писал, что высокую поэзию, как и поэзию мысли, в России способны воспринимать только юные женщины. И Чаадаеву легче было писать, обращаясь не к закованному в официальную или кружковую броню мужчине.

Стоит отметить интеллектуальный штамп. Согласно устоявшемуся мнению, западники - это порождение Петербурга, а славянофилы Москвы. Но вот признанный всеми как мыслитель, ориентированный на Запад, Петр Яковлевич Чаадаев всю жизнь прожил в Москве. И адрес его с 1833 г. оставался один и тот же: Новая Басманная, 20.

Замечательная женщина, Екатерина Гавриловна Левашева (умерла в 1839 г.), считавшая мыслителя избранником Провидения, в знак преклонения перед Петром Яковлевичем поселила его во флигеле своей усадьбы. Там Чаадаев прожил до конца дней, на годы пережив Левашеву.

Летом 1983 г., путешествуя с другом Александром Косицыным по Поветлужью, обмеряя полуразрушенные церкви и записывая их истории, наблюдая сохранившуюся послереволюционную разруху, мы зашли в селе Воскресенском в местный клуб, где я неожиданно обнаружил письмо сына Екатерины Левашевой Валерия к Чаадаеву. Позднее я не удержался и вставил это письмо в рассказ «Историческая справка» (1986), опасаясь, что иначе оно пропадет. Рассказ был написан от третьего лица.

«Он встал из-за стола и принялся листать книги, стоявшие на стеллажах. Взял в руки “Записки краеведов”. Место издания - Горький, год - 1980. И тут вспомнил, что, похоже, об этом сборнике говорила благолепная старушка, дочь страхового агента. Быстро открыл оглавление. Оно! Статья Н. Ю. Сергутиной “Валерий Николаевич Левашев”. Лихорадочно нашел нужную страницу, сел за стол, вытащил из кармана куртки мятый блокнот, шариковую ручку. Наткнулся глазами на строчки: “В левашевском архиве на Ветлуге имелись чаадаевские рукописи, которые, возможно, еще 
отыщутся в горьковских архивных, музейных, библиотечных фондах". И несколькими строчками ниже в подтверждение своих слов автор статьи приводила в собственном переводе с французского письмо В. Н. Левашева П. Я. Чаадаеву:

“Только вчера, дорогой Петр Яковлевич, я прочел Ваше столь любезное письмо - Дельвиг забыл передать мне его. Спешу поблагодарить Вас за память; я никогда не забуду, что Вы были другом моей матери, и это главный источник моего уважения и любви к Вам. Я оставил службу, весьма мне досаждавшую, чтобы обосноваться в деревне и оставаться там до полной выплаты всех наших приватных долгов... В бумагах отца я нашел несколько Ваших рукописей, доро-

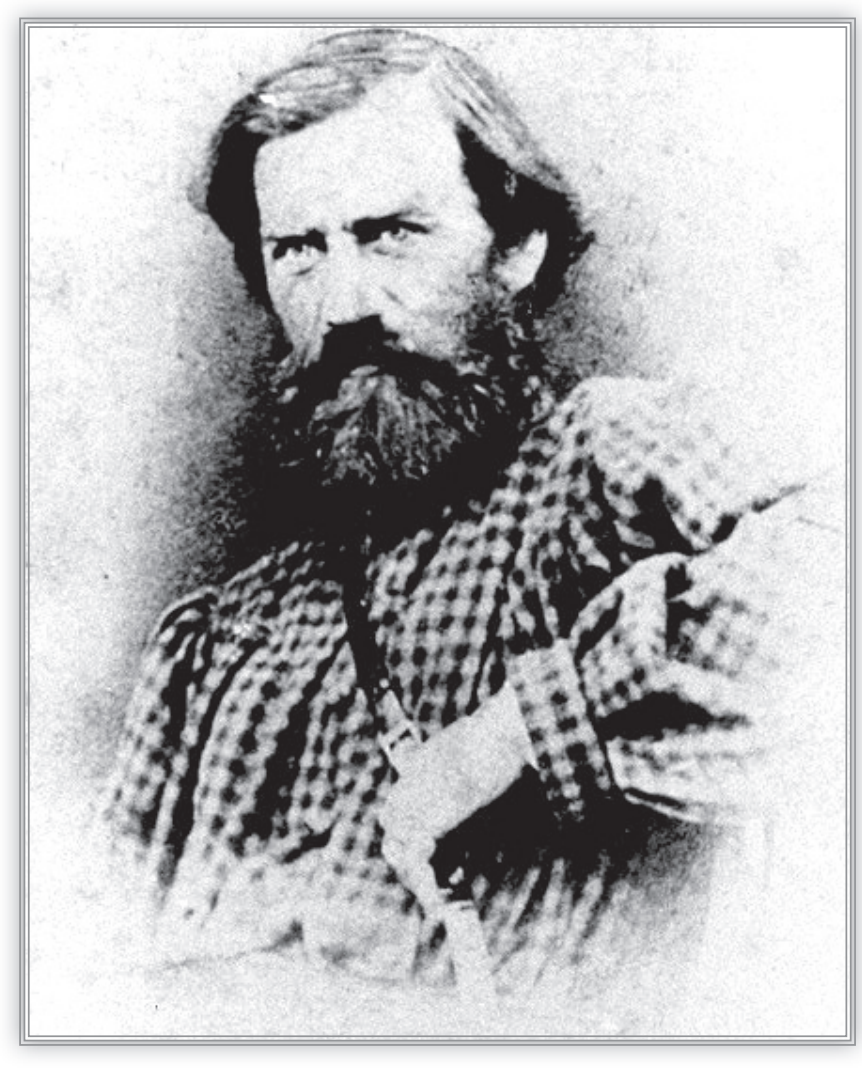

Валерий Николаевич Левашев.

Русская фотография в Москве гой Петр Яковлевич, и прочел их с несказанным удовольствием. Они напомнили мне счастливые и спокойные дни, проведенные в кругу семьи. Эти письма, прочитанные мною со всем вниманием, на какое я только способен, вызвали во мне горячее, но почти несбыточное желание - я хотел бы получить все Ваши рукописи, так как желал бы посвятить свою жизнь чтению и наукам. Прощайте, дражайший Петр Яковлевич, будьте здоровы и не забывайте того, кто Вас искренне любит. Валерий”» (Кантор, 1990: 358-359).

От него ждали мысли и поучения. Конечно, к восстанию он не мог стремиться. Пушкин воспринимал грядущее восстание как творчески-эротический акт:

\footnotetext{
Мы ждем с томленьем упованья

Минуты вольности святой,

Как ждет любовник молодой

Минуты верного свиданья.
}

Чаадаев так не чувствовал, не ощущал себя молодым любовником, а потому был холоднее и трезвее. Как писал Мандельштам: «Мысль Чаадаева - строгий отвес к традиционному русскому мышлению. Он бежал, как чумы, этого бесформенного рая» (Мандельштам, 1993: 198). «Басманный мыслитель» надеялся, что и в России «пришло время говорить простым языком разума. Нельзя уже более 
ограничиваться слепой верой, упованием сердца; пора обратиться прямо к мысли» (Чаадаев, 1991а: 434). Однако его упования остались тщетными. В русской философии в конечном счете победила славянофильская туземная школа, как ее называл Чаадаев, проклявшая «самодвижущийся нож разума» (Киреевский, 1979: 251).

Быть может, Чаадаев вербовал прозелитов и в основном прозелиток, обращая их в католичество, и в этом-то заключался его общественный пафос? Не принимая православия в принципе? Недаром противники именовали его маленьким аббатиком.

Чаадаев не был против православия, хотя и писал, что мы приняли эту конфессию от разлагавшейся Византии; он был против «ветреной толпы», осатаневшей на почве славянофильски ориентированной православной ксенофобии, того, что сегодня называют «православием головного мозга». Чаадаев называл славянофилов новой школой: «Но вот является новая школа. Больше не нужно Запада, надо разрушить создание Петра Великого, надо снова уйти в пустыню» (Чаадаев, 1991a: 530). Его вопрос был о том, «<...> следует ли идти вперед по пути, начертанному Евангелием, которое не знает рас помимо одной человеческой, или же следует обратить человечество вспять, вернуть его к исходной точке, на которой оно стояло в то время, когда слово человечность еще не было изобретено, т.е. следует ли вернуться к язычеству? Дело, по существу, в том, что вся эта философия своей колокольни, которая занята разбивкой народов по загородкам на основании френологических и филологических признаков, только питает национальную вражду, создает новые рогатки между странами, она стремится совсем к другим целям, а не к тому, чтобы создать из человеческого рода один народ братьев» (Там же: 476). Повторю: речь шла о «ветреной толпе», набросившейся на Петра Яковлевича. Но, скажем, независимый от мнений массы Хомяков высоко ценил его.

А православную церковь «басманный мыслитель» совершенно очевидно выводил из-под удара своей критики. Он писал, что всеми своими героическими поступками Россия обязана нашей «смиренной церкви». В «Апологии сумасшедшего» он возвращается к этой проблеме и без ажитации, в сущности, продолжая идеи первого письма, произносит панегирик: «<..> было преувеличением не воздать должного этой церкви, столь смиренной, иногда столь героической, которая одна утешает за пустоту наших летописей, которой принадлежит честь каждого мужественного поступка, каждого прекрасного самоотвержения наших отцов, каждой прекрасной страницы нашей истории» (Там же: 536).

Для России он видел великое будущее.

Замечено это не было никем. Письмо было воспринято обществом как злостная клевета на Россию. После публикации в 1836 г. первого Философического 


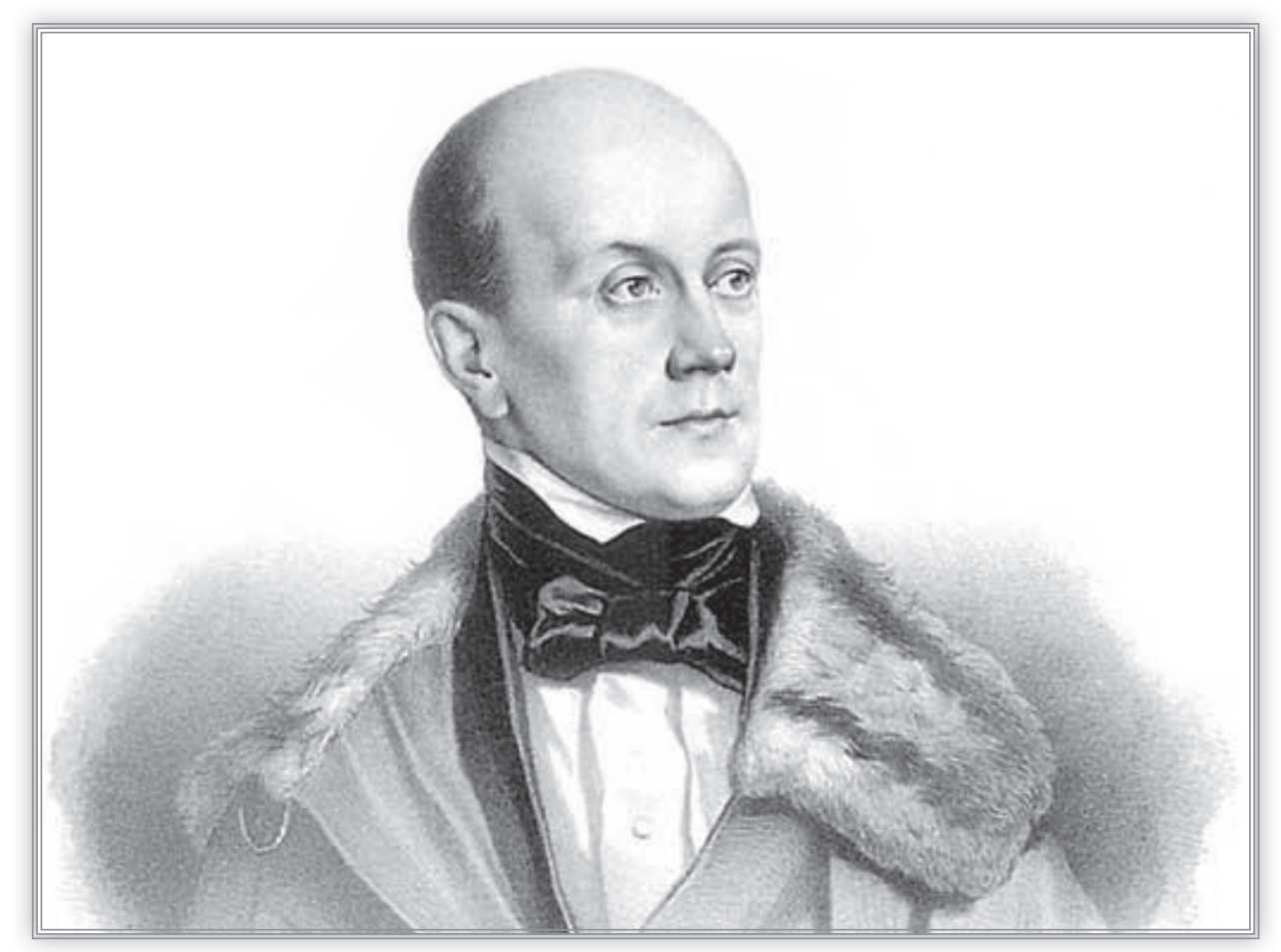

П. Я. Чаадаев. Портрет работы М. А. Алофа. 1848. Литография.

Мастерская Гатие (Париж). Всероссийский музей А. С. Пушкина (С.-Петербург)

письма в «Телескопе», писал Жихарев, про «Чаадаева узнали люди, которые никогда его не видали, кругом своего существования от него совершенно отдаленные, никогда не имевшие никакой вероятности с ним встретиться и без того, быть может, про него во всю жизнь бы не сведавшие» (Жихарев, 1989: 91-92) .

Сам Чаадаев винил в личной катастрофе «патриотическую» толпу: «<...> катастрофа, только что столь необычайным образом исказившая наше духовное существование и кинувшая на ветер труд целой жизни, является в действительности лишь результатом того зловещего крика, который раздался среди известной части общества при появлении нашей статьи, едкой, если угодно, но конечно вовсе не заслуживавшей тех криков, какими ее встретили. В сущности, правительство только исполнило свой долг; можно даже сказать, что в мерах строгости, применяемых к нам сейчас, нет ничего чудовищного, так как они, без сомнения, далеко не превзошли ожиданий значительного круга лиц» (Чаадаев, 1991а: 533). И далее его излюбленная мысль: «<...> инстинкты масс бесконечно более страстны, более узки и эгоистичны, чем инстинкты отдельного человека, что так называемый здравый смысл народа вовсе не есть здравый смысл; что не в людской толпе рождается истина; что ее нельзя выразить числом; наконец, что во всем своем могуществе и блеске человеческое сознание всегда обнаруживалось только в одиноком уме, который является центром и солнцем его сферы. Как же случилось, что в один прекрасный день я очутился перед разгневанной публикой, - публикой, чьих похвал я никогда не добивался, чьи ла- 


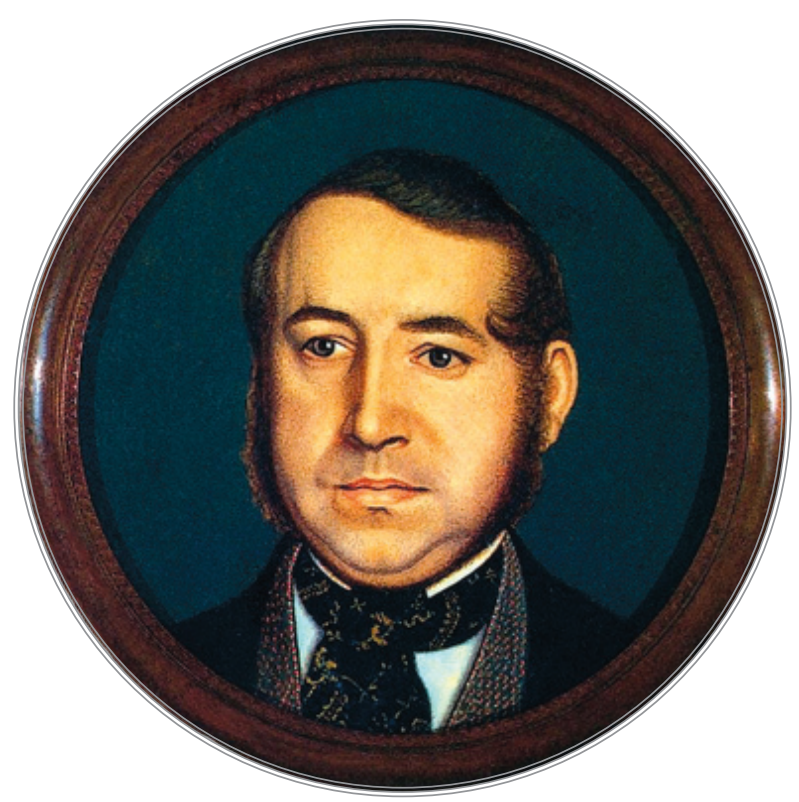

Неизвестный художник.

Портрет Филиппа Филипповича Вигеля. 1839. Бумага, акварель, гуашь. Москва, Государственный музей А. С. Пушкина

ски никогда не тешили меня, чьи прихоти меня не задевали? <...> Этого я не в состоянии объяснить» (Там же: 524).

Реакция на письмо была неоднозначной, в основном его пафос не был принят, писались пасквили. Филипп Филиппович Вигель, знакомец Пушкина с юных лет, считал, что поступок Чаадаева объясняется его непомерным тщеславием:

«Он был первый из юношей, которые тогда полезли в гении. На беду, стоя с полком в Царском Селе, познакомился он и сблизился с лицейским воспитанником Пушкиным. Все поэты немного льстецы с теми, коих любят; Пушкин польстил ему стихами, а Карамзин по добродушию своему ласкал его. Это совершенно вскружило ему голову. Никто не замечал в нем нежных чувств к прекрасному полу: сердце его было слишком преисполнено обожания к сотворенному им из себя кумиру. Когда изредка случалось ему быть с дамами, он был только что учтив; они же между собою называли его настоящим розаном, а он был Нарцисс, смертельно влюбленный в самого себя. Чтобы дать понятие о чудовищном его самодовольствии, расскажу следующее, тогда мною слышанное. В наемной квартире своей принимал он посетителей, сидя на возвышенном месте, под двумя лавровыми деревьями в кадках; справа находился портрет Наполеона, с левой Байрона, а напротив его собственный, в виде скованного гения, с надписью:

Он в Риме был бы Брут,

В Афинах Демосфен,

А здесь лишь офицер гусарской» (Вигель, 2000: 249).

Пушкинские строчки, как видим, искажены. У Пушкина: «в Афинах Периклес». Знаменитый поэт Языков, друг пушкинской юности, написал злобные стихи, похожие на политический донос:

Вполне чужда тебе Россия,

Твоя родимая страна!

Ее предания святые 
Ты ненавидишь все сполна.

Ты их отрекся малодушно,

Ты лобызаешь туфлю пап, -

Почтенных предков сын ослушный,

Всего чужого гордый раб!

(«К Чаадаеву», около 1837)

В стихотворении «Н. М. Языкову» (1846) поэтесса Каролина Павлова назвала эти стихи криком «языческого гнева». Следом за Языковым и клеветником Филиппом Вигелем пошли сегодня постмодернисты российского разлива, которые не перестают упрекать Чаадаева в тщеславии, позерстве, нелюбви к людям, умственном бессилии (Д. В. Галковский, Р. С. Черепанова и др.). Оппоненты - за исключением Пушкина, подробно проанализировавшего основные положения философии старшего друга - назвали чаадаевское письмо клеветой на Россию. Все это были люди душевные, но не духовные. Что же написал Пушкин? Вот его строки от 19 октября 1836 г. (дорога из Петербурга в Москву): «Благодарю за брошюру, которую вы мне прислали. Я с удовольствием перечел ее, хотя очень удивился, что она переведена и напечатана. Я доволен переводом: в нем сохранена энергия и непринужденность подлинника. Что касается мыслей, то вы знаете, что я далеко не во всем согласен с вами. Нет сомнения, что схизма (разделение церквей) отъединила нас от остальной Европы и что мы не принимали участия ни в одном из великих событий, которые ее потрясали, но у нас было свое особое предназначение. Это Россия, это ее необъятные пространства поглотили монгольское нашествие. Татары не посмели перейти наши западные границы и оставить нас в тылу. Они отошли к своим пустыням, и христианская цивилизация была спасена. Для достижения этой цели мы должны были вести совершенно особое существование, которое, оставив нас христианами, сделало нас, однако, совершенно чуждыми христианскому миру, так что нашим мученичеством энергичное развитие католической Европы было избавлено от всяких помех. <...> Пробуждение России, развитие ее могущества, ее движение к единству (к русскому единству, разумеется), оба Ивана, величественная драма, начавшаяся в Угличе и закончившаяся в Ипатьевском монастыре, - как, неужели все это не история, а лишь бледный и полузабытый сон? А Петр Великий, который один есть целая история!» (Пушкин, 1982: 289). Для Пушкина вся послетатарская история России есть не только история становления "русского единства», но и возвращения России в Европу. Кстати, обращением к истории Петра Пушкин весьма твердо объявил свою позицию.

Чаадаев считал, что он ведом Божиим духом, но, как сказано в Евангелии: «Душевный человек не принимает того, что от Духа Божия, потому что он почитает это безумием; и не может разуметь, потому что о сем надобно судить духовно» 
(Кор., 2, 14). Напомню слова Фамусова из комедии Грибоедова о Чацком (Чаадаеве, по мысли Тынянова):

Безумный! что он тут за чепуху молол!

Низкопоклонник! тесть! и про Москву так грозно!

Вообще-то в эти годы тема безумия волновала русских писателей. «Не дай мне Бог сойти с ума», - писал Пушкин. Гоголь создает гениальную повесть «Записки сумасшедшего», где герой Поприщин мечтает о достойном его поприще и соглашается только на роль короля Испании.

Сумасшедший может говорить только чепуху, слова его всерьез воспринимать нельзя. Действительно горе от ума. Или точнее - Горе уму, как первоначально называлась пьеса. Удивительное предчувствие Грибоедова - за десять лет до события. С этой точки зрения можно взглянуть на потрясающий ход императора Николая І. Позволю себе высказать предположение, что, объявив Чаадаева сумасшедшим, император защитил его. Почему можно назвать вердикт императора гениальным? Все слова безумного обнуляются. Резолюция Николая от 22 октября была ясна и определённа: «Прочитав статью, нахожу, что содержание оной смесь дерзостной бессмыслицы, достойной умалишенного; это мы узнаем непременно, но не извинительны ни редактор журнала, ни цензор. Велите сейчас журнал запретить, обоих виновных отрешить от должности и вытребовать сюда к ответу» (цит. по: Тарасов, 1986: 309).

То есть статья достойна умалищенного, а с сумасшедшего какой спрос.

После приговора императора уже никому нельзя было всерьез воспринимать слова «басманного мыслителя». И тем самым необходимость расправы над клеветником, которой требовали молодые патриоты, сама собой отпала. Семидесятилетнего Сократа за клевету на Афины обвиняли молодые судьи, а потом по их наветам за казнь философа проголосовал ареопаг. Сорокадвухлетнего Чаадаева хотели казнить студенты. Как писал Жихарев: «Я слышал, будто студенты московского университета приходили к своему начальству с изъявлением желания оружием вступиться за оскорбленную Россию и переломить в честь ее копье и что граф Строганов, тогдашний попечитель, их успокаивал» (Жихарев, 1989: 100). В каком-то смысле это можно считать началом бесовщины. Приговор императора спас Чаадаева.

Это была красиво разыгранная комедия. Не забудем, что Николаю нравился гоголевский «Ревизор». Безумным Чаадаева со всей определенностью называли многие, но не император, от которого пошел этот «диагноз». Неслучайно все сразу изменилось, когда из Европы возвратился в Москву генерал-губернатор князь Д. В. Голицын. «При первом свидании с Чаадаевым 
он расхохотался со словами: “Çа n’a que trop duré; il faut pourtant que cette farce finisse. [Это слишком долго тянулось, нужно, наконец, покончить с этим фарсом. Фр.]”. Деятельным ходатайством князя Голицына Чаадаев был прощен через один год и один месяц, к годовщине вступления на престол Николая I, приходившейся на 20 ноября. Резолюция императора Николая I на докладе князя Дмитрия Голицына 30 октября 1837 г. гласит: “Освободить от медицинского надзора под условием не сметь ничего писать”. Снова к Чаадаеву приехал полицеймейстер - на сей раз объявить, что “по просьбе генерал-губернатора ему возвращается свобода и прекращается полицейский надзор"» (Там же: 102-103).

Но интересно, что сам Чаадаев принял звание безумца и (повторю)

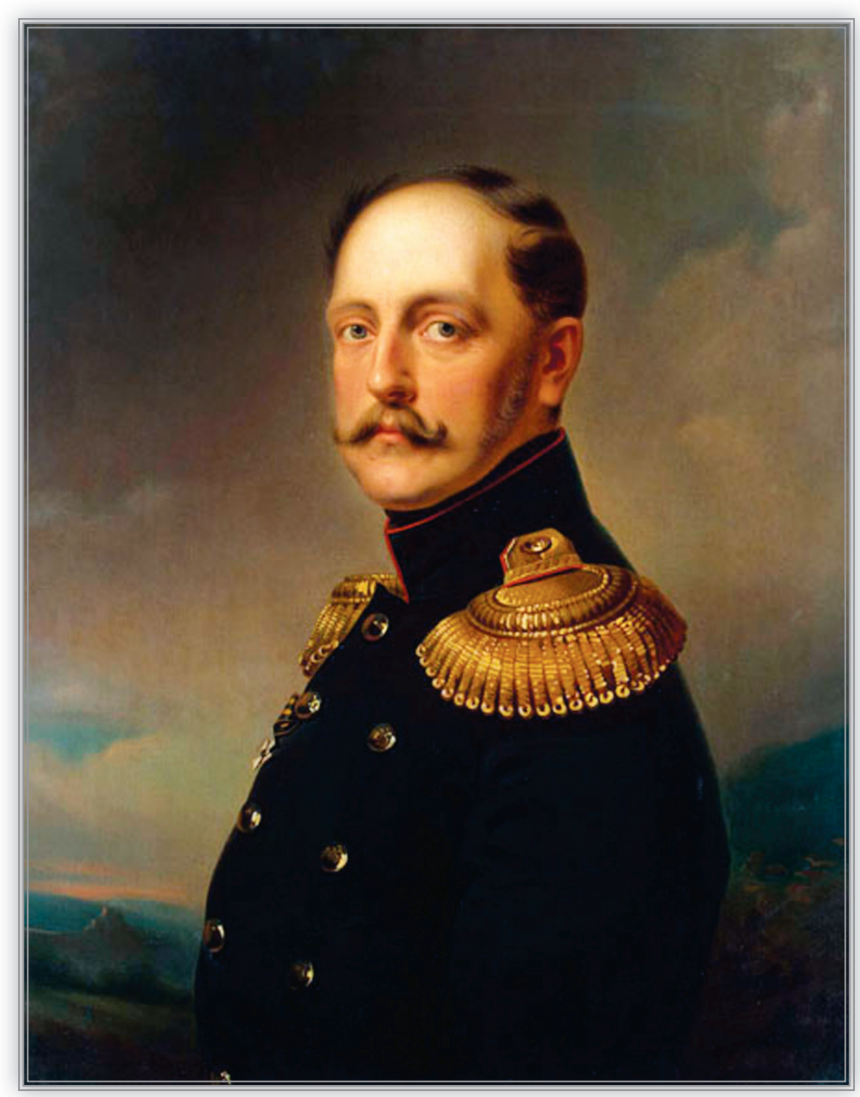

Император Николай I.

Е. И. Ботман.

Портрет императора Николая І.

Холст, масло. 1850-е гг.

Государственный Эрмитаж, С.-Петербург даже написал «Апологию сумасшедшего». Впрочем, со времен шекспировского Гамлета интеллектуалы охотно принимали на себя роль сумасшедших, понимая, что она их не унижает. Напротив, поднимает до уровня датского принца. А жанру «апологии» положил начало Платон своей «Апологией Сократа». Впрочем, был и еще один ученик Сократа - знаменитый Ксенофонт, тоже написавший «Апологию». Надо сказать, что обе апологии были ответом на сочинение Поликрата «Обвинение Сократа», в котором доказывалась политическая неблагонадежность Сократа и его безумие. И ученики выступили в защиту учителя, вложив ему в уста защитительную речь. Жанр не умер после «случая Сократа». Потом был Апулей с «Апологией, или Речью в защиту себя самого от обвинения в магии». Возможно, и Апулея Чаадаев читал, но Платона и Сократа он не раз поминал в своих текстах. Скажем, писал: «нет ничего понятнее огромной славы Сократа единственного умершего из-за убеждений человека, смерть которого древний мир мог наблюдать. Этот единственный пример героизма убеждений должен был действительно поразить эти народы» (Чаадаев, 1991: 426). Из-за убеждений мог погибнуть и Чаадаев. 
От обвинения в политической неблагонадежности он пытается защититься в своей «Апологии»: «Прекрасная вещь - любовь к отечеству, но есть еще нечто более прекрасное - это любовь к истине. Любовь к отечеству рождает героев, любовь к истине создает мудрецов, благодетелей человечества. Любовь к родине разделяет народы, питает национальную ненависть и подчас одевает землю в траур; любовь к истине распространяет свет знания, создает духовные наслаждения, приближает людей к Божеству. Не через родину, а через истину ведет путь на небо» (Чаадаев, 1991а: 523-524). При этом нельзя забывать, что Россию он защищал с оружием в руках, что еще подростком переживал за ее судьбу: «В щербатовском семействе играли какое-то представление по случаю торжествования тильзитского мира. Дело было летом и в деревне. Чаадаев ушел на целый день в поле и забился в рожь, а когда его там отыскали, то с плачем объявил, что домой не вернется, что не хочет присутствовать при праздновании такого события, которое есть пятно для России и унижение для государства» (Жихарев, 1989: 56). Это тоже своего рода безумие, но государственно-патриотическое.

Любопытно, что слава безумца не загнала мыслителя в духовное подполье, а напротив, сделала его духовным центром тогдашнего образованного общества. Флигель на Басманной стал местом паломничества интеллектуальной элиты, его выезды в Английский клуб становились своего рода событиями. И до самой смерти он оставался в центре интеллектуальных споров. Скажем, через два часа после его кончины 14 апреля 1856 г. к нему приехал А. С. Хомяков - поздравить с наступающей Пасхой, но нашел его уже мертвым. Более того, общеизвестное католичество Чаадаева, как видим, не отвратило от него православных мыслителей. Об этом феномене писал после выпущенного М. О. Гершензоном двухтомника Чаадаева Федор Степун: «И все-таки проповедовавший всю жизнь католичество - церковное, философское и социальное, - Чаадаев сам остался до конца своей жизни православным и от России никогда не требовал перехода в католичество. Как у Парменида с его метафизикой неподвижного уживается гипотетическая физика движения, так у Чаадаева рядом с его католической метафизикой уживается какое-то гипотетическое и эмпирическое признание великой истины православия. Связь между католической проповедью Чаадаева и его признанием православной России кроется, конечно, не в логической последовательности его историко-философского построения, но в той психологической необходимости, которая его “отвлеченное чувство истории” сейчас же превратила в конкретное историческое чутье, как только мысль Чаадаева вплотную подошла к проблеме России.

Этой непоследовательностью, в которой проявилась великая мудрость чаадаевского построения, держится его историческое значение, значение звена, сковывающего и примиряющего западничество и славянофильство. Вместе с западниками, но углубленнее, чем они, видел он в Европе судью и совесть России, вме- 


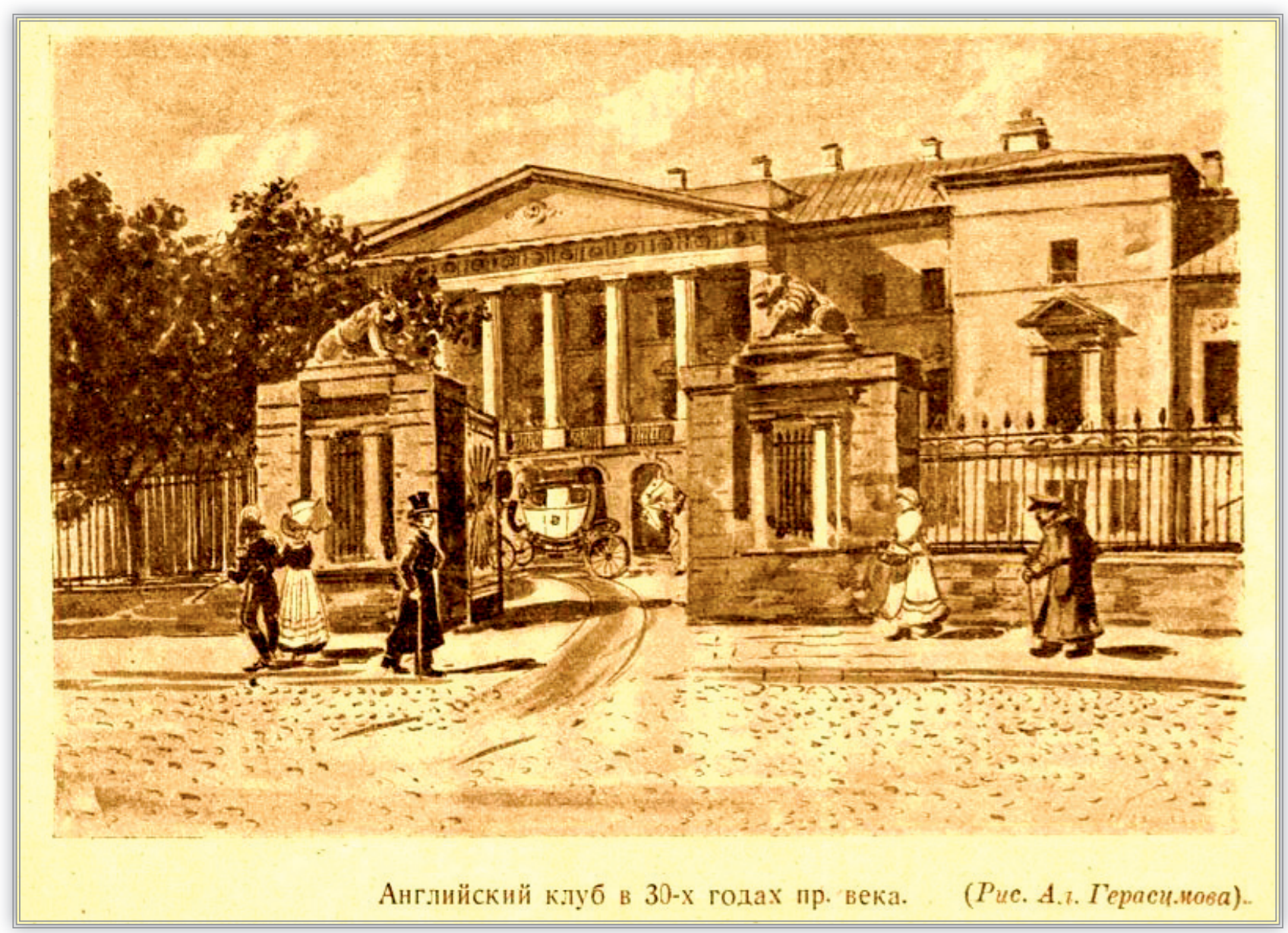

Английский клуб в 1830-х гг.

Рис. Ал. Герасимова. 1926

сте с славянофилами, но напряженнее и тревожнее, чем они, ждал он великого слова России, ее откровения от ее собственных православных глубин» (Степун, 1998: 374).

Много страшнее закончила свою жизнь женщина, которой Чаадаев адресовал свои письма - Е. Д. Панова, в девичестве Улыбышева. Сохранилось ее письмо к нему вскоре после объявлении о его сумасшествии.

В России так повелось, что за мужчину отвечает женщина. Ольгу Ивинскую посадили, а Бориса Пастернака не тронули; посадили жену Молотова, а Молотов продолжал служить вождю верой и правдой. Ведется это со времен Адама, общий грех свалившего на Еву: она, мол, меня научила. «Адам сказал: жена, которую Ты мне дал, она дала мне от дерева, и я ел» (Быт., 3, 12). Чаадаева оставили в его жилище, а Панова вытерпела все мыслимые и немыслимые издевательства. Жизнь ее окончилась чудовищно. Муж, конечно, ее записал в умалишенные, чтобы забрать ее имущество, поместить в сумасшедший дом и жениться на другой. Сохранилось ее письмо Чаадаеву, в котором она рассказывает, как муж, воспользовавшись сообщением о сумасшествии мыслителя, решил и жену объявить безумной. Вот отрывок, в котором рассказывается о русском барском Освенциме: 
«Я сделала печальное открытие, что соединила свою судьбу с самым презренным из людей <...> эта смесь лицемерия, жестокости и низости, которые он больше не находил нужным от меня скрывать, провозглашая самые строгие принципы и держа в доме свою любовницу, которую я сама вытащила из нищеты и с которой обращалась вначале, как с сестрой. Все эти бесчестные дела, совершавшиеся у меня на глазах, возмущали меня до такой степени, что я не хотела даже скрывать от него мое презрение. <..> Тогда Панов объявил мне, будто я так больна, что жизнь моя в опасности, и предложил подписать письмо, в котором, вознеся самую трогательную хвалу его добродетелям, - я должна была умолять своих братьев оставить ему после моей смерти имение, где мы жили. <..> Видя, что я противостою и его просьбам, и его угрозам, он заключил меня в комнату, где наглухо забил окна и дверь, и через маленькое отверстие, проделанное в стене, мне давали еду, от которой отказались бы и собаки. Часто оставалась я сидеть на полу, без еды и питья, целыми днями погруженная в глубокую тьму, всю мебель убрали, в 10-12 градусов мороза комнату эту никогда не отапливали. Поверите ли, сударь, что он приходил смотреть на меня через это отверстие, и рассматривал меня с насмешливой улыбкой. Всякий раз он приходил, чтобы сказать мне то, что вернее всего могло разбить мое сердце. Он извещал меня о смерти маменьки, или об отъезде моего брата за границу; я верила всем его ужасным новостям и испускала крики тоски и отчаяния, которые он передразнивал со своею любовницей, издеваясь надо мной! Скажите, неужели Вы считаете меня способной выдумывать такие вещи! Наконец, я почувствовала, что схожу с ума; холод, голод, отчаяние, болезнь - у меня не было больше сил бороться против стольких бед; моей навязчивой идеей стала мысль о смерти. Когда они приходили насладиться моим несчастьем, я на коленях умоляла о смерти, я ничего больше не хотела, я говорила только одно: дай мне умереть. Тогда, надеясь, что я действительно сошла с ума, он сказал своей любовнице: “Слава Богу”, да, он сказал “Слава богу!”, - “Теперь нам нечего бояться, выздоровеет она или нет, теперь она сумасшедшая, и никто не поверит ей, надо отвезти ее в Москву, поместить в сумасшедший дом, я буду управлять ее состоянием, и все будет кончено!”. Несчастная женщина, вспомнив, быть может, мою дружбу и заботу, которую я проявляла к ней, несомненно испытывала угрызения совести и тайком принесла мне маленький флакон, запечатанный желтым воском и содержащий крепкую водку ${ }^{1}$, у меня не хватило мужества проглотить этот страшный яд, но я долго сохраняла его спрятанным в своем платье!» (Чаадаев, 1991б: 457-458)

17 декабря 1836 г. Московское губернское правление освидетельствовало умственные способности Екатерины Дмитриевны Пановой по просьбе ее мужа и определило считать ее сумасшедшей и поместить в лечебное заведение.

\footnotetext{
${ }^{1}$ Крепкая водка - старинное название азотной кислоты.
} 
И вот последние сведения о ней от Н. Н. Вильде, внука ее брата Александра Улыбышева (Кайдаш, 1989), который вспоминал дворовую избу и живущую в ней старую безногую женщину, которую называли презрительно-насмешливо «философка» - корреспондентку Чаадаева Екатерину Дмитриевну Панову, родную сестру известного музыковеда Александра Улыбышева. Ей носили обед из барского дома. Самый образ древней старухи с непонятным именем «философки» остался, по словам мемуариста, в его памяти страшным, даже сказочным.

Впрочем, и Чаадаев умирал тяжело и необычно. Жил он бедно, и жилище его, как замечал Ф. Тютчев,

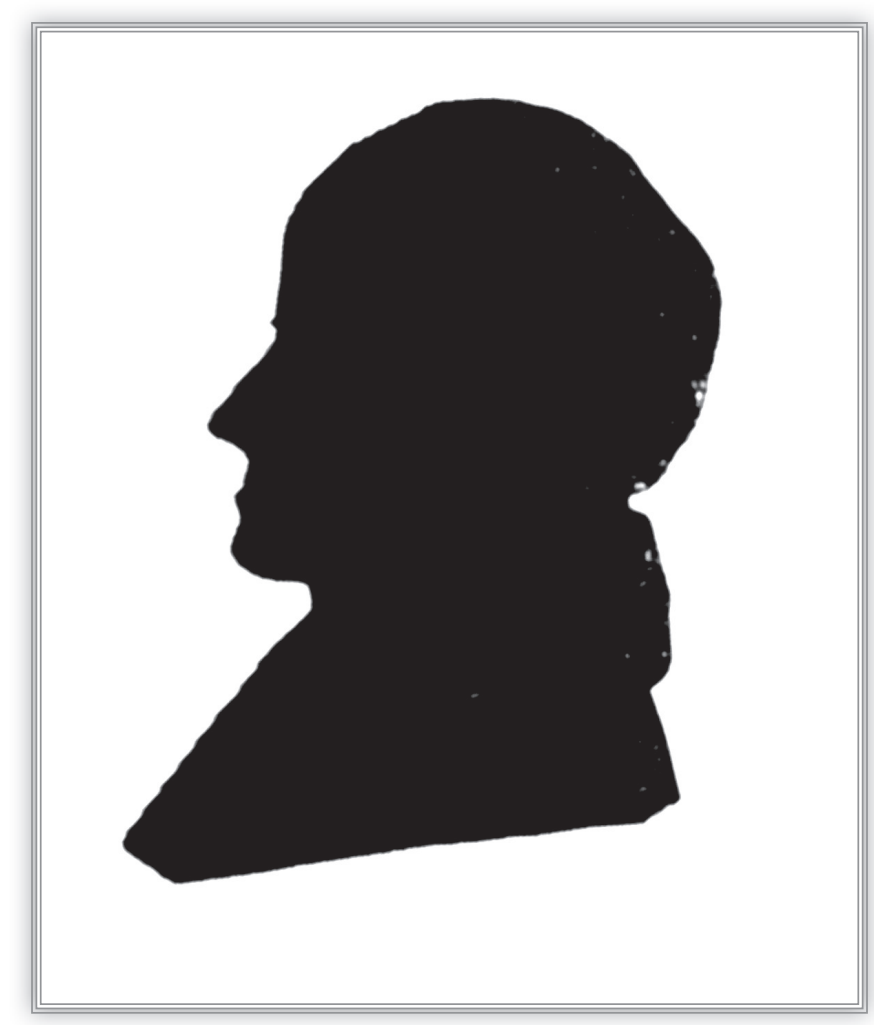

П. В. Киреевский.

Силуэтный портрет П. Я. Чаадаева одним его духом держалось. Но в возрасте шестидесяти одного года он начал вдруг катастрофически стареть. Через неделю от начала странного заболевания он походил на девяностолетнего старца. Очевидно, на то имелись медицинские причины, хотя ранее ему прочили долгую жизнь. Но можно прочесть этот факт символически. Мыслитель сказал все, что было дано. Дальнейшая жизнь становилась пустой. Вот она и закончилась. Бог позвал Своего избранника к Себе.

Стоит привести письмо Хомякова: «Почти все мы знали Чаадаева, многие его любили, и, может быть, никому не был он так дорог, как тем, которые считались его противниками. Просвещенный ум, художественное чувство, благородное сердце, - таковы те качества, которые всех к нему привлекали; но в такое время, когда, по-видимому, мысль погружалась в тяжкий и невольный сон, он особенно был дорог тем, что и сам бодрствовал и других побуждал, - тем, что в сгущающемся сумраке того времени он не давал потухать лампаде и играл в ту игру, которая известна под именем: “жив курилка”. Есть эпохи, в которые такая игра уже большая заслуга» (Хомяков, 1861: 720). Один из видных славянофилов, П. В. Киреевский, создал силуэт Чаадаева.

Но и позже «Апология сумасшедшего» становилась поводом для глубоких историософских размышлений и запретов. В 1860 г. Жихарев передал этот текст Н. Г. Чернышевскому, реальному руководителю «Современника», для публикации. 


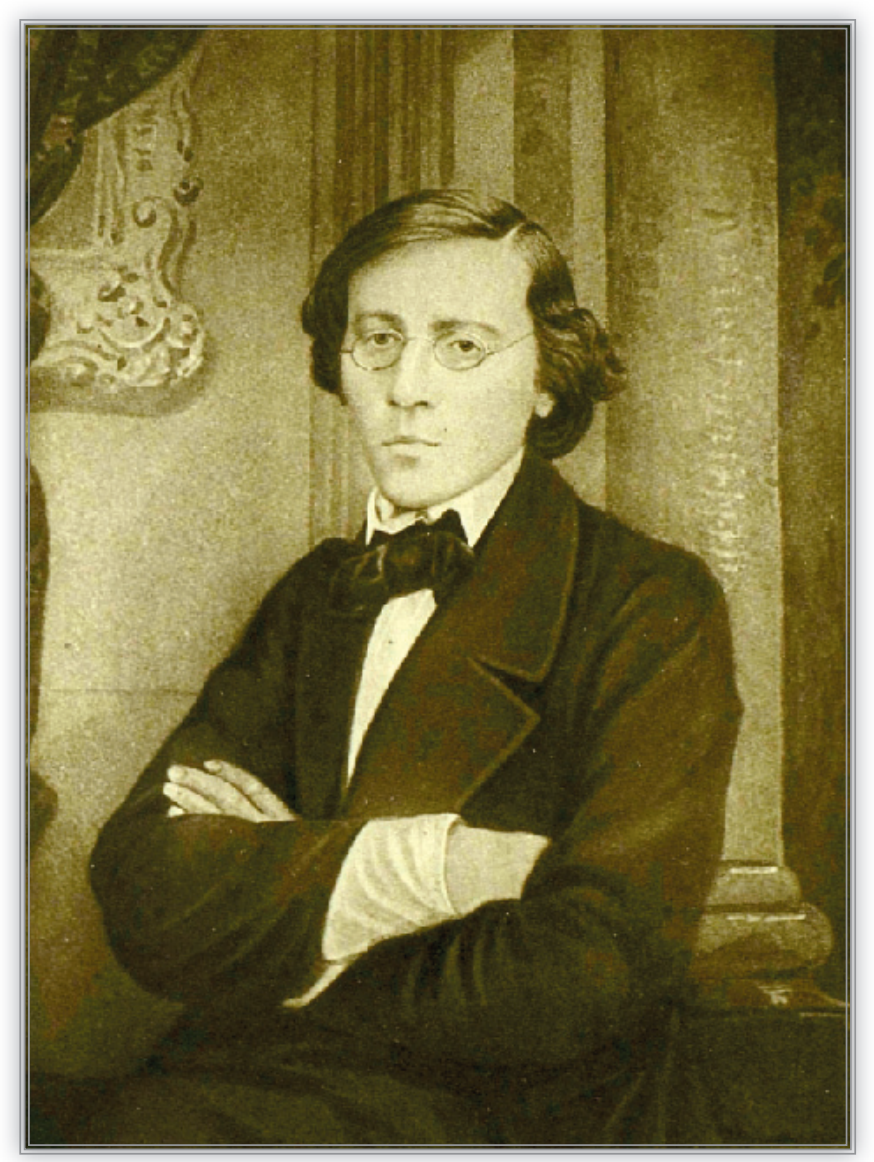

Н. Г. Чернышевский.

Фотография В. Я. Лауфферта. 1859 г.

Чернышевский подготовил его для печати, сопроводив одной из лучших своих статей. Чаадаев поставил вопрос о том, что такое Россия и сумел ли Петр Первый европеизировать ее. Один из наиболее резких и нетривиальных ответов прозвучал из уст руководителя «Современника». Чернышевский писал: Чаадаеву «казалось, что Петр Великий нашел свою страну листом белой бумаги, на котором можно написать что угодно. К сожалению, - нет. Были уже написаны на этом листе слова, и в уме самого Петра Великого были написаны те же слова, и он только еще раз повторил их на исписанном листе более крупным шрифтом. Эти слова не “Запад” и не “Европа", как думал Чаадаев; звуки их совершенно не таковы: европейские языки не имеют таких звуков. Куда французу или англичанину и вообще какому-то ни было немцу произнести наши Щ и Ы! Это звуки восточных народов, живущих среди широких степей и необозримых тундр» (Чернышевский, 1861: 610). Поэтому, по мысли Чернышевского, целью Петра была не европеизация страны, а создание такого положения, чтобы русский царь стал сильнее соседей. Ему нужно было сильное регулярное войско, мощный флот, но он понимал, что элементы военного могущества ненадежны, если его подданные сами не обучатся вести военную часть, как ведут ее немцы, стало быть, представлялась ему надобность выучить русских быть хорошими офицерами, моряками, инженерами, литейщиками. Раз пошедши по этой дороге, занявшись мыслью устроить самостоятельное русское войско и флот, и, заимствуя у немцев или шведов военные учреждения, заимствовал, кстати, мимоходом и все вообще, что встречалось его взгляду. Впрочем, это понимал и Пушкин, заметив, что Россия вошла в Европу под звук строящихся кораблей и грохот пушек.

Но Чернышевский выдвинул в этой статье одну из самых резких своих идей о произволе как основе устроении русской жизни: «Основное наше понятие, упорнейшее наше предание - то, что мы во все вносим идею произвола. Юридические формы и личные усилия для нас кажутся бессильны и даже смешны, 
мы ждем всего, мы хотим все сделать силою прихоти, бесконтрольного решения; на сознательное содействие, на самопроизвольную готовность и способность других мы не надеемся, мы не хотим вести дела этими способами: первое условие успеха, даже в справедливых и добрых намерениях, для каждого из нас то, чтобы другие беспрекословно и слепо повиновались ему. Каждый из нас маленький Наполеон или, лучше сказать, Батый» (Там же: 616). А от Батыя до Николая I,

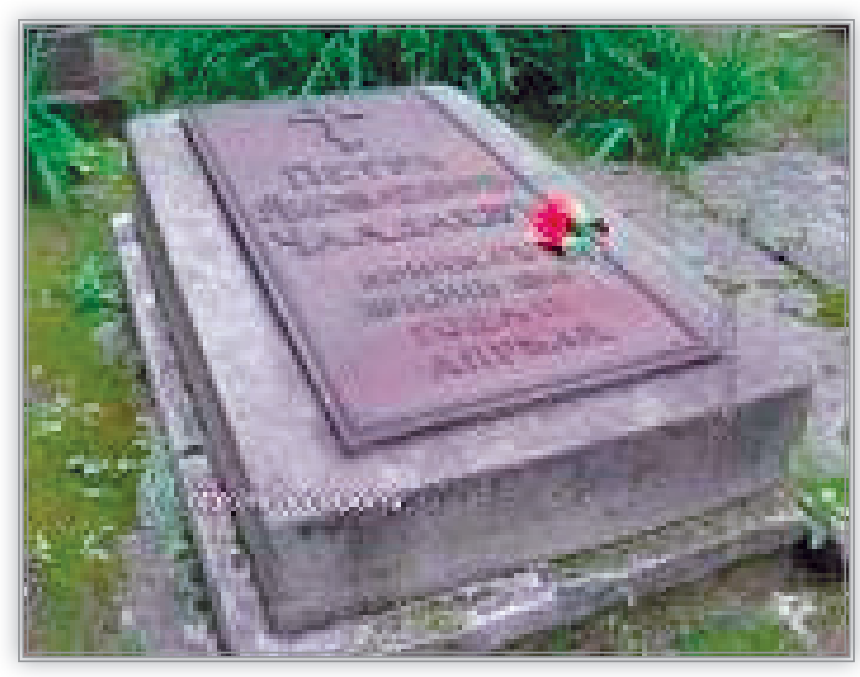

Могила Чаадаева на Донском кладбище Александра II и «эффективного менеджера» Сталина легко можно провести прямую линию.

Это тоже смелое до сумасшествия высказывание. Текст Чаадаева и статья Чернышевского были запрещены к публикации, а руководитель «Современника» еще и за свою свободную мысль получил два десятилетия Сибири. И раз зашла речь о свободе, то стоит закончить мой текст о Чаадаеве словами Мандельштама: «Он ощущал себя избранником и сосудом истинной народности, но народ уже был ему не судья. Какая разительная противоположность национализму, этому нищенству духа, который непрерывно апеллирует к чудовищному судилищу толпы. У России нашелся для Чаадаева только один дар: нравственная свобода, свобода выбора. Никогда на Западе она не осуществлялась в таком величии, в такой чистоте и полноте. <...> Я думаю, что страна и народ уже оправдали себя, если они создали хоть одного совершенно свободного человека, который пожелал и сумел воспользоваться своей свободой» (Мандельштам, 1993: 200).

Чаадаев пожелал и сумел.

\section{Литература}

Вигель Ф. Ф. (2000) Записки. М.: Захаров.

Жихарев М. И. (1989) Докладная записка потомству о Петре Яковлевиче Чаадаеве // Русское общество 30-х годов XIX в. Люди и идеи. Мемуары современников. М.: Издательство Московского университета.

Кайдаш С. Н. (1989) Сила слабых. Женщины в истории России (XI-XIX вв.). М.: Советская Россия. Электронный ресурс: [код доступа]: https:/www.litmir.me/br/?b=243366\&p=38 (дата обращения: 3 ноября 2019).

Кара-Мурза А. А. (2019) Итальянское путешествие Петра Чаадаева (1824-1825). М.: Аквилон. 
Кантор В. К. (1990) Историческая справка // Кантор В. К. Повести и рассказы. М.: Советский писатель. С. 327-362.

Киреевский И. В. (1979) Критика и эстетика. М.: Искусство.

Мандельштам О. Э. (1993) Петр Чаадаев // Мандельштам О. Э. Собр. соч. в четырех томах. М.: Арт-Бизнес-Центр. Т. І. С. 194-200.

Пушкин А. С. (1982) Письмо к П. Я. Чаадаеву. 1836. 19 октября // Переписка А.С. Пушкина. В 2-х т. Т. 2. М.: Художественная литература. С. 287-292.

Степун Ф. А. (1998) П. Я. Чаадаев // Чаадаев: Pro et contra. СПб.: РХГУ. С. 370-374.

Тарасов Б. Н. (1986) Чаадаев. М.: Молодая гвардия.

Хомяков А. С. (1861) Полное собрание сочинений. Т. 1. М.

Чаадаев П. Я. (1989) Сочинения. М.: Правда.

Чаадаев П. Я. (1991а) Философические письма. Письмо первое // Чаадаев П. Я. Полное собрание сочинений и избранные письма. В 2-х т. Т. 1. М.: Наука. С. 320-339.

Чаадаев П. Я. (1991б) Письмо к И. Д. Якушкину. 1838. 2 мая // Чаадаев П. Я. Полное собрание сочинений и избранные письма. Том II. М.: Наука. С. 105-106.

Чернышевский Н. Г. (1950) Апология сумасшедшего // Чернышевский Н. Г. Полное собрание сочинений в 15 т. М.: ГИХЛ. Т. VII. Статьи 1860-1861 годов. С. 592-618. 


\section{THE APOLOGY OF THE MADMAN, OR REASON AGAINST THE MADNESS OF THE CROWD}

\section{Vladimir Kantor}

DSc in Philosophy, Professor, Tenured Professor, School of Philosophy, Faculty of Humanities, National Research University Higher School of Economics. Laboratory Head: International Laboratory for the Study of Russian and European Intellectual Dialogue. National Research University Higher School of Economics, Russian Federation.

Journal "Philosophical letters. Russian and European dialogue". Editor-in-Chief.

Address: Staraya Basmannaya, 21/4,

Moscow, Russian Federation 105066. Office A 215

E-mail: vlkantor@mail.ru

\section{References}

Chaadaev P. (1989) Sochineniya [Collected Works], Moscow: Pravda (in Russian).

Chaadaev P. (1991a) Filosoficheskie pis'ma. Pis'mo pervoe [Philosophical Letters. The First Letter] Polnoe sobranie sochinenij i izbrannye pis'ma [Collected Works and Letters], 2 Vols, vol. 1, pp. 320-339, Moscow: Nauka (in Russian).

Chaadaev P. (1991b) Pis'mo k I. D. Jakushkinu. 1838. 2 maja [Letter to I. D. Yakushkin. 1838. May 2] Polnoe sobranie sochinenij i izbrannye pis'ma [Collected Works and Letters], 2 Vols, Vol. 2, pp. 105-106, Moscow: Nauka (in Russian).

Chernyshevskij N. (1950) Apologiya sumasshedshego [Apology of the Madman] Polnoe sobranie sochinenij v 16 tomah [Collected Works, 16 Vols], Vol. 7, Moscow: State Publishing House of Fiction, pp. 592-618 (in Russian).

Kajdash S. (1989) Sila slabyh. Zenshchiny v istorii Rossii (XI-XIX vv.) [The Strength of the Weak. Women in the History of Russia (XI-XIX Centuries)], Moscow: Sovetskaya Rossiya. Available at: https://www.litmir.me/br/?b=243366\&p=38 (accessed 3 november 2019) (in Russian).

Kara-Murza A. (2019) Ital'janskoe puteshestvie Petra Chaadaeva (1824-1825) [The Italian Journey of Peter Chaadaev (1824-1825)], Moscow: Akvilon (in Russian).c

Kantor V. (1990) Istoricheskaya spravka [Historical Note] // Kantor V. Povesti i rasskazy [Novels and Stories]. Moscow: Sovetskij pisatel', pp. 327-362 (in Russian).

Homjakov A. (1861) Polnoe sobranie sochinenij [Collected Works] Vol.1, Moscow (in Russian).

Kireevskij I. (1979) Kritika i estetika [Criticism and aesthetics]. Moscow: Iskusstvo (in Russian).

Mandel'shtam O. (1993) Petr Chaadaev [Peter Chaadaev] Sobranie sochinenij v chetyreh tomah [Collected Works], 4 Vols, Vol. 1, Moscow: Art-Biznes-Centr, pp. 194-200 (in Russian). 
Pushkin A. (1982) Pis'mo k P. Ja. Chaadaevu. 1836. 19 Oktjabrja [Letter to P. Y. Chaadaev. 1836. October 19]. Perepiska A.S. Pushkina [Correspondence of A. S. Pushkin], 2 Vols, Vol.1, Moscow: Hudozhestvennaja literature, pp. 287-292 (in Russian).

Stepun F. (1998) P. Ja. Chaadaev. Chaadaev: Pro et contra, Saint-Petersburg: Russian Christian humanitarian Academy, pp. 370-374 (in Russian).

Tarasov B. (1986) Chaadaev. Moscow: Molodaya gvardiya (in Russian).

Vigel' F. (2000). Zapiski. Moscow: Zaharov (in Russian).

Zhiharev M. I. (1989). Dokladnaya zapiska potomstvu o Petre Yakovleviche CHaadaeve [Memo to posterity about Peter Yakovlevich Chaadaev]. Russkoe obshchestvo 30-h godov XIX v. Lyudi i idei. Memuary sovremennikov [Russian society 30-IES of XIX century. People and ideas. Memoirs of contemporaries], Moscow: Izdatel'stvo Moskovskogo universiteta (in Russian). 